\title{
The symbiosis of oral history and agonistic memory: Voices of 68 and the legacy of the past in Northern Ireland
}

\author{
Chris Reynolds
}

\begin{abstract}
This article offers a reflection on the potency of combining oral history and agonistic memory. Via the specific example of a recent collaboration between the author and National Museums NI on the subject of 1968, it will be argued that the symbiotic relationship between this methodological approach and theoretical underpinning provides a potentially effective response to the current and pressing challenge of managing the legacy of the Troubles as part of the Northern Irish peace process. The success of this approach in the particular and difficult context of Northern Ireland suggests that there are potential lessons for other post-conflict societies coming to terms with the challenges of their own difficult pasts.
\end{abstract}

Keywords: Oral history, agonistic memory, Northern Ireland, 1968, museums, post-conflict, difficult pasts.

Note on author: Chris Reynolds is Professor of Contemporary European History and Memory Studies at Nottingham Trent University. His main research interests are in relation to the events of 1968 from a French, Northern Irish, and European perspective. In addition to a wide range of articles and chapters on these topics, he is the author of Memories of May '68: France's Convenient Consensus (University of Wales Press, 2011) and Sous les pavés ... The Troubles: Northern Ireland, France and the European Collective Memory of 1968 (Peter Lang, 2015).

Chris.reynolds@ntu.ac.uk

https://orcid.org/0000-0002-3704-8425

(C) The author(s) 2021. This is an open access article licensed under a

Creative Commons Attribution-NonCommercial-NoDerivs 4.0 Unported License 


\section{Introduction}

This article offers a reflection on the potency of combining oral history and agonistic memory. Via the specific example of a recent collaboration between the author and National Museums NI (NMNI) on the subject of 1968, it will be argued that the symbiotic relationship between this methodological approach and theoretical underpinning provides a potentially effective response to the current and urgent challenge of managing the legacy of the Troubles as part of the Northern Irish peace process. The success of this approach in the particular and difficult context of Northern Ireland suggests that there are potential lessons for other post-conflict societies coming to terms with the challenges of their own difficult pasts. Starting with a brief overview of the context that has seen Northern Ireland move from conflict to peace, there then follows an outline of the challenges faced by the peace process in overcoming the legacy of the past. The potency of oral history as a potential mechanism in post-conflict contexts is then analysed before a focus on its effectiveness and limitations in the case of post-Troubles Northern Ireland. As a response to the obstacles faced by current initiatives on this issue, it will then be argued that underpinning such an approach with agonistic memory, as exemplified by the recent Voices of 68 project at NMNI, provides a fruitful response to the specific challenges facing Northern Ireland with potential opportunities for its application elsewhere.

\section{Northern Ireland: from the 'Troubles' to an era of peace}

Ireland's troubled history did not begin in 1968. Indeed, the era now commonly referred to as the 'Troubles' was just the latest and most recent chapter in a long and fractious relationship with England that stretches as far back as the 17th century (Foster 1988, Lee 1989). In the thirty years following 1968, Northern Ireland experienced a period of sectarian conflict that resulted in the deaths of over 3600 people and left its population traumatised for generations to come (Hennessey 1997, McKittrick $\&$ McVea 2001, Patterson 2007). The three decades of violence that, crudely speaking, pitted the Catholic / Nationalist / Republican (CNR) community against that of the Protestant / Unionist / Loyalist population (PUL), was eventually brought to a close with the signing of the Good Friday Agreement (GFA) in 1998. ${ }^{1}$ In the period since the onset of peace, the region has made great strides towards a certain degree of normalcy. There have been many, many positive changes that are welcomed by all

${ }^{1}$ The published version of this landmark peace deal can be read here: https://assets.publishing.service. gov.uk/government/uploads/system/uploads/attachment_data/file/136652/agreement.pdf 
concerned and ought to be celebrated. In addition to the end of daily deaths and destruction that punctuated the Troubles era, one can also point to significant improvements for Northern Irish society that are examples of the rewards that peace has brought (Bairner 2008, Tonge 2013: 92-3, Byrne 2014). For example, there has been huge economic development with lots of inward investment that, during the conflict, was simply not forthcoming. This has led to much improvement in terms of general infrastructure and improved standards of living. Particularly symbolic in this respect has been the explosion of the local tourist industry. On the foundations of peace, and bolstered by local sporting successes and a booming film industry, tourism has become a totemic example of just what the region is capable of in this context of peace (Boyd 2019). One could also point to the strengthening of devolved political institutions that has witnessed former enemies share power and lay the political foundations of a brighter future.

However, it would be wholly incorrect to suggest that Northern Ireland can be considered as having overcome the consequences of the Troubles (Armstrong et al. 2019). It almost goes without saying that a thirty-year conflict of the nature of the Troubles would leave deep and difficult wounds that could not simply be overcome by economic progress and sporting successes. Indeed, in the period since 1998, the peace process has charted a path that has been littered with hugely difficult issues that have required careful management before peace could continue to advance (Power 2011, Cochrane 2013). Underscoring these difficulties is the fact that, whilst the GFA did bring violence to an end, it did not necessarily solve the underlying issues that characterised the conflict (Dingley 2005, Cochrane 2013). Divisions remain, as do the associated tensions and difficulties, which explains why peace is described as a process, and by no means mission accomplished.

One could point to a whole range of issues that continue to provide significant obstacles for the advancement and consolidation of peace. In recent years, tensions have continued to build around issues related to identity that have manifested themselves through the expression of divisions in relation to questions of flag-flying, marching, culture, languages, and debates on rights (Fenton 2019, Savage 2019, Walker \& Carrol 2019). ${ }^{2}$ Trying to filter down the accommodating principles of the GFA across this range of highly sensitive and emotive issues has, and continues to be, hugely challenging for all parties interested in maintaining peace. The inherent tensions of the community are translated by stark differences over such issues and in turn risk perpetuating differences and present significant challenges for the process. Take, for example, the recent debate around Brexit. The UK's 2016 decision to leave

${ }^{2}$ The 2012-13 Belfast City Hall flag protests are just one example in recent years of the ongoing tensions and divisions that are never far from the surface in Northern Irish society (Halliday \& Ferguson 2016). 
the European Union exposed the underlying issue that has defined tensions in Northern Ireland since 1921: the border between the north and south of Ireland (Tonge 2016, Cochrane 2020). In taking this decision, the UK risks undermining one of the central tenets of the GFA - the careful management of the border. In so doing, it has brought discussions around the future of the border to the fore and consequently exposed tensions within the Northern Irish community over this crucial issue. Broadly speaking, the PUL community and their political representatives backed the Brexit decision and insisted that any future agreement must ensure that Northern Ireland falls into line with Great Britain with the region maintaining its political union. The CNR community and its political representatives broadly opposed Brexit, fearing that it would result in the inevitable imposition of a hard border between north and south. Such a scenario would, in their eyes, not only jeopardise the fundamentals of the GFA but could also provide major problems for its long-term objective of a united Ireland. It is no surprise, then, that the question of Northern Ireland has been amongst the most problematic and potentially dangerous issues in the entire Brexit debate. The manner with which it has exposed underlying tensions around the border question - as exemplified in the spate of serious PUL unrest in opposition to the Northern Ireland protocol in the spring of 2021 (O'Toole 2021) - is but further evidence that the GFA may have ended violence but the fundamental issues that characterise divisions remain. Another central challenge facing the maintenance of peace in Northern Ireland, which is arguably just as sensitive as that of the border, relates to the highly sensitive issue of managing the past.

\section{The peace process and the challenge of the past}

As Northern Ireland has emerged from its period of conflict, one issue of particular importance and sensitivity has been how the past is remembered and passed on to future generations (Hamber \& Kelly 2016, McGrattan \& Hopkins 2017). This has been particularly problematic for many reasons. Fundamentally, the persistence of division has meant that the antagonistic manner with which the different communities have constructed their narratives on how the region finds itself where it is today has not simply disappeared with the advent of peace. During the Troubles, each community sought to make sense of their predicament and justify their particular stance where stories of the past played a critical role (Lundy \& McGovern 2001). This would lead to the emergence of starkly different memory communities that effectively built up opposing and contested narratives that only further served to entrench the divisions that characterised the conflict (Lawther 2014). As attempts are made to try to 
build a new and peaceful future, it is obvious that such contested narratives on the past cannot be allowed to continue to sow divisions in the same manner and this explains why so much attention has been paid to this particular issue by all parties involved in trying to chart a course towards sustainable peace.

In the immediate aftermath of the GFA, and despite some commitments to addressing this issue, little in the way of concrete measures were put in place to confront the legacy of the past. So hard-won was the cessation of violence, and given the wide range of other urgent and potentially deal-breaking questions (decommissioning, the status of prisoners, etc.), it is clear now that the peace process needed to acquire a certain degree of maturity before this highly sensitive issue could be met head on (Power 2011, Cochrane 2013). So how and why is the past such a difficult issue? Firstly, the fact that divisions perpetuate means that communities in Northern Ireland continue to look back on what happened and why through the optic of such divisions (McDowell \& Braniff 2014, Viggiani 2014, Smyth 2017). As a result, parallel and contested narratives on the past are still very much in place and provide a significant challenge before, if ever, they can be reconciled, or at the very minimum be stripped of their potential to undermine the advancement of peace (Brown \& Grant 2016, Beiner 2018). Furthermore, the temporal proximity of the conflict means that many people continue to live with its devastating consequences and, as a result, find it very difficult to engage with this question in a constructive manner (Bell 2003). Such sensitivities are not helped by ongoing and deeply difficult questions about the role of the state and security forces and accusations of collusion, as well as other hugely questionable acts and tactics deployed by the various protagonists of the conflict (Dawson 2014). The combination of such factors helps explain why the 'legacy' debate is integral to securing a peaceful future whilst at the same time it is such a significant challenge. Legacy issues go well beyond the question of contested memories and feed into and off sensitivities around identity, culture, and symbols. Such factors translate into significant and substantial issues (such as the plight of victims, reparations, compensation, memorialisation, and commemoration, to name but a few) that remain unresolved and have a tangible and important impact on the daily lives of much of the Northern Irish population (Pinkerton 2012, Brewer \& Hayes 2015, Dawson 2017). The inherent difficulties in confronting these challenges provide some explanation as to why, in the early years of the peace process, the issue of the past was very much kept in the background while the foundations for peace were laid.

However, in more recent years, as the peace process has bedded in and gained sufficient maturity, increasingly, the issue of managing the legacy of the past has risen to prominence as a top priority (Potter, 2016). Indeed, one can point to a range of 
initiatives that have emerged in recent years that have placed the question of the past as a central priority for governments in Belfast, Dublin, and London. ${ }^{3}$ The 2014 publication of the Stormont House Agreement (SHA) set out a range of measures that sought to provide concrete steps towards constructing a strategy for overcoming the difficulties of the region's divided past. ${ }^{4}$ One consequence of the SHA was the creation of a commission on Flags, Identity, Culture and Tradition (FICT). ${ }^{5}$ This body was set up to produce a report with proposals on overcoming the central challenges facing the future of the peace process, one of which was the issue of the legacy of the conflict. More recently, the government launched a public consultation entitled 'Addressing the Legacy of Northern Ireland's Past', the results of which are to be fed into a carefully constructed strategy. ${ }^{6}$ A striking common denominator across these initiatives has been the insistence on the deployment of oral history as an important mechanism in whatever strategy emerges. ${ }^{7}$ Before discussing why this makes sense within the particular context of Northern Ireland, let us first briefly turn our attentions to the general effectiveness of oral history and how it has become an increasingly prominent feature in the quest to build peace in post-conflict societies around the world.

\section{Oral history and its effectiveness in post-conflict societies}

The debate around the use and effectiveness of oral history is well trodden (Frisch 1990, Portelli 1991, Thompson 1998, Della Porta 2014). General consensus exists on how its deployment offers a distinctive and useful means to treat the past that brings a certain number of advantages beyond those resulting from traditional historical methods. For example, there is broad agreement that the use of oral testimonies allows for the construction of historical narratives that invert any top-down approach and provide the grounds for the construction of narratives from below (Lynd 1993). As such, the result is an inclusive tapestry of perspectives that helps create a more

${ }^{3}$ Such initiatives include the 2014 Stormont House Agreement (NIO 2014), the formation of the Flags, Identity, Culture and Tradition (FICT) commission in 2016 (https://www.fictcommission.org/en), and the 2018 Northern Ireland Office public consultation on 'Addressing the Legacy of Northern Ireland's Past' (NIO 2018).

${ }^{4}$ NIO (2014).

${ }^{5} \mathrm{https} / / /$ www.fictcommission.org/en

${ }^{6}$ NIO (2018).

${ }^{7}$ This is by no means the first time that such an approach has been advocated. Indeed, one could view such initiatives as building on the recommendations of the 2009 Eames and Bradley report (CPG 2009) as well as the work carried out by bodies such as the influential Healing Through Remembering. For more information, see https://healingthroughremembering.org. 
representative picture of how the past was experienced and is remembered. This broader base of perspectives, it is argued, enables the construction of a narrative that goes beyond the stereotypical gatekeepers by providing space for previously marginalised perspectives. The potential that emerges, it follows, is for a genuine challenge to dominant, often limited, hegemonic narratives of the past (Bryson 2016: 306-11). This is not to suggest that oral history provides all the answers when attempting to overcome the inadequacies of traditional methods. Nor is it true that this particular methodological approach is without its limitations and critics (Jessee 2011). Indeed, much caution is required when handling and managing first-hand testimonies. In particular, careful management and awareness of context are required when assessing whether such testimonies can be taken at face value (Strangleman 2017). As Maurice Halbwachs has argued, our recollections of the past are largely determined by the needs of the present - an awareness of the motivations and contexts that lie behind individual testimonies is essential in ensuring that such material is handled in an effective and constructive manner (Halbwachs 1925, 1950). Much work has been carried out to probe the methodological robustness of the process of gathering, analysing, and disseminating oral histories to help ensure that its effectiveness is not compromised, and the full potential is realised (Thomson 2007, Aras et al. 2012, Ritchie 2014). It is perhaps the increased sophistication around oral history as a methodological approach that explains its growing prominence and, in particular, its increasingly prevalent deployment in post-conflict societies.

One is able to identify a huge number of examples from right across the world where, in locations emerging from a period of conflict and trying to lay the foundations of a brighter future, oral history forms a central part of peacebuilding strategies (Humphrey 2002, Schaffer \& Smith 2004, Bickford 2007, Hamber 2009). Examples from Rwanda, Bosnia-Herzegovina, Argentina, Sierra-Leone, and South Africa, to name but a few, all demonstrate the increasingly prevalent turn towards oral history as a fruitful mechanism to help chart the very complex post-conflict course in a diverse range of contexts and circumstances (Field 2011, Bouka 2013, Park 2013, Kaifala 2014, Wali 2018). That oral history has risen to such prominence in such difficult circumstances is to be understood by the distinctive characteristics it brings to how the past is handled. As argued above, such an approach breaks out of the limiting, dominant, official narratives and encourages a much more inclusive gathering of voices to help make sense of the past. It is, in many respects, recognition that, in order for post-conflict societies to take positive steps into the future, there is a requirement to firstly go back and effectively handle the past. Oral history provides the grounds for such an approach to be bottom-up and one that cultivates a terrain to encourage a much broader base of the population affected to become involved. By breaking out of official paradigms and institutions it enables a much more thorough, representative, 
and complete picture of the past to be constructed, one where all sectors of society feel they have a space to voice their own experiences, understandings, and memories. Only by broadening the base in this way is it possible to gather as representative picture of the past as possible and, in so doing, widen the net of perspectives gathered by demonstrating that everyone's story must at least be given the opportunity to be heard. The act of gathering testimonies enables people who have hitherto felt marginalised in how the memory of conflict has been constructed to feel that their voices and their perspectives are part of the complex picture of making sense of conflict. This feeling of participation is an essential component in laying the foundations for peace and is a further explanation why such an approach has become increasingly prevalent and popular in the difficult and challenging contexts of post-conflict societies.

Having established the credentials of oral history as a widely recognised and deployed methodological approach in post-conflict societies, it is hardly surprising that, in the context of Northern Ireland, one is able to highlight many examples of peacebuilding projects and initiatives that have embedded oral history as a core element of their methodological approach. This is something that has not gone unnoticed by state actors as they struggle to find solutions to this most urgent of challenges facing the peace process.

\section{The deployment of oral history in post-Troubles Northern Ireland: effectiveness and limitations}

A common denominator across the range of initiatives launched in response to the legacy challenge is the emphasis on the deployment of oral history. For example, in the 2014 SHA, one of the key recommendations was the creation of an Oral History Archive that would provide a platform for citizens to recount and deposit their personal experiences of the conflict. This emphasis on oral history has been maintained as the process has continued to (very slowly) develop and, as evidenced in both the public consultation on 'Addressing the Legacy of the Past' and the summary of its findings published in 2019, this particular element remains a priority for those trying to scope out the strategy and is an approach that appears to have the backing of the general public. ${ }^{8}$

Such an evident trend is partly explained as a consequence of the wider recognition as to the effectiveness of oral-history-based strategies in post-conflict circumstances. However, from a more localised perspective, one can also point to a whole range of very successful and well-developed projects that have placed oral history at their core

${ }^{8}$ NIO (2019). 
and have developed during the years since the onset of peace and which are great examples of what can be achieved by deploying such a strategy (Hamber \& Kelly 2016, McEvoy \& Bryson 2016: 84-6). For example, Elizabeth Crooke provides an analysis of a striking case of how and why the oral history approach has proved so popular and potent in one particular Belfast community that found itself at the heart of the Troubles (2007: 124-8). In her analysis of the Duchas Sound Archive that has provided a platform for residents of the Falls Community to offer testimonies of their experiences of life in the community during the conflict, Crooke demonstrates how 'the conceptual foundations of oral history are very suited to the objectives of the [Falls Community] council and reflect its concerns' (127). It is, she argues, the provision of such a platform that empowers citizens who have felt marginalised that best explains why this has been such a successful example for the challenge of peacebuilding in Northern Ireland. ${ }^{9}$

The combination of increasing general recognition of the effectiveness of oral history with the concrete examples of its effective and popular application at grassroots level in Northern Ireland goes a long way towards helping us make sense of why this particular approach has gained such momentum in recent and ongoing work on the construction of considered strategies as part of the peace process. However, there are limitations to how such projects have emerged and potential risks in terms of what they can do in order to overcome the divisions that continue to lie at the core of the challenge of dealing with the region's difficult past. Whilst these grass-roots projects have provided potent platforms for citizens to find a voice in negotiating their postconflict trajectories, many are focussed within specific communities. As such, they foster and develop the construction of communal memories that rarely come into contact with those beyond their own communities and potentially run the risk of consolidating intercommunal divides. ${ }^{10}$ It is perhaps this particular challenge that has prevented any real progress being made by those bodies advocating the creation of an oral history archive coming up with a clear and structured sense of how it would work, both in terms of collecting testimonies, and in relation to their dissemination (Bryson 2016). It is one thing providing a platform for people to deposit their recollections and accounts of the conflict, it is an altogether different challenge to make sure that this very process does not run the risk of entrenching divides and generating further tension (McEvoy \& McConnachie 2012, Dybris McQuaid 2016: 65-6).

\footnotetext{
${ }^{9}$ Other examples of such projects include the Corrymeela Community Project (https://www.corrymeela. org) or the Causeway Coast and Glens Borough Council's PEACE action plan (https://keep.eu/projects/ 20034/Causeway-Coast-and-Glens-Bo-EN/).

${ }^{10}$ It should be noted that many cross-community activities and projects are also part of this peacebuilding process. A range of examples can be found via the following: https://www.peaceinsight.org/conflicts/ northern-ireland/
} 
However, this is not to say that an oral history approach is to be avoided: on the contrary. Indeed, what is proposed here, and exemplified by a pilot project with NMNI, is the deployment of oral history with the added theoretical underpinning of agonistic memory. Such an approach, it will be argued, provides the necessary scaffolding for the full exploitation of the potential unleashed through the deployment of oral history whilst at the same time it negates the risk that a free-for-all platform provides in creating more problems than it resolves.

\section{The symbiosis of oral history and agonistic memory}

In their 2016 article On Agonistic Memory, Anna Cento Bull and Hans Lauge Hansen added a new memory mode to an ever-growing list (Cento Bull \& Hansen 2016). Drawing on the work of Chantal Mouffe, they proposed a new approach to memory that encourages the bringing together of contested perspectives on the past as a constructive and potentially fruitful means to overcoming the difficulties inherent in dominant mnemonic practices. Mouffe has effectively argued that the post-war shift towards cosmopolitanism was one that, whilst understandable and not without its benefits, has in recent years reached its limits and has in fact become the source of much contemporary tension (Mouffe 2000). The drive to frame our politics around the need for consensus and agreement that so defined the post-1945 era was one that inevitably led to the marginalisation of certain communities that did not sit within the dominant model. It is precisely such communities, it is argued, that find themselves on the margins of society that have risen to prominence and have underpinned the rise of populist politics that has become such a threat in recent times (Mouffe 2005). Taking the European Union as an example, Mouffe outlines how this cosmopolitan project has marginalised large swathes of the European population and it is these very marginalised people, who feel they have no representation and no voice, who are the driving forces behind the greatest threats to the European project (Mouffe 2012). In order to overcome this challenge, Mouffe argues that we need to move to a model based on agonism, that is, one that is not afraid of different ideas, one that welcomes the clash of perspectives, and one that reintroduces the notion of conflict to how democracies can and should function. By providing the space for such divergent perspectives and making this clash part of how our democracy works, we can overcome the inevitable re-emergence of antagonism that the cosmopolitan approach set out to eradicate.

Cento-Bull and Hansen mapped such a paradigm onto mnemonic practices and argued that the way in which dominant memories had been forged in the same era followed a similar cosmopolitan approach that, through the quest for consensus, may 
well have led to some sort of general agreement, but ultimately marginalised those perspectives on the past that sit outside the prevailing discourse. The absence of any space for divergent perspectives has afforded those forces challenging the dominant model the possibility to instrumentalise tensions around difficult moments in the past to pose serious problems and generate tensions that have inevitably fed into mounting political instabilities (Cento Bull \& Hansen 2016: 393). They, like Mouffe, argue that the time has come for an approach to memory based on agonism.

In order to test and refine the theory of agonistic memory, a Horizon2020-funded project entitled UNREST was undertaken between 2016 and 2019. ${ }^{11}$ As part of this extensive project, the team embarked on two case studies: one which examined mass grave exhumations in Spain, Poland, and Bosnia, whilst the other explored representations and methodological approaches of five European war museums. One of the findings of these case studies that is of particular pertinence in the present discussion relates to the use of oral history. The project team concluded that, whilst there were many examples of the deployment of oral history within the museums in question, they were 'used to offer plural narratives in terms of gender, age, and social background within a consensual over-arching perspective' (Cento Bull \& Hansen 2020). It could be argued, therefore, that a potentially fruitful opportunity is being missedeven more so when one considers the contention that there exists an inherently mutually reinforcing relationship between the deployment of oral history and agonistic memory.

Sidelined voices find themselves marginalised precisely because they have not been able to find a place in, or have been ostracised from, the drive to formulate a consensus on the past. Therefore, by deploying an agonistic approach to the past, the quest for consensus is removed and those people who felt that their voice previously had no place are made to feel as though they do belong, even if their particular perspective is not in keeping with the traditionally dominant narrative. The convergence of the broader-based methodological approach of oral history and the theoretical underpinning of agonism works to maximise the potential of each individual element, rendering them perfect partners in the quest for a much more constructive approach to the past. It is precisely this combination that lies at the heart of the effectiveness and success of the NMNI project entitled Voices of 68.

\footnotetext{
${ }^{11} \mathrm{http} / / /$ www.unrest.eu
} 


\section{Voices of 68}

Between October 1968 and February 1969, Northern Ireland experienced a period of upheaval with the emergence of a movement that sought to challenge the state in relation to issues around the question of civil rights (Purdie 1990, Prince 2007, Reynolds 2015). This relatively brief moment would mark a significant turning point in the recent history of the region and witnessed a sequence of events that saw the movement swell, forcing the government to offer concessions, before eventually awakening sectarian tensions that preceded the onset of the conflict that would become known as the Troubles. The descent into violence in the aftermath of this moment characterised the manner in which this period would be remembered. Memories of this era would, like everything else, be divided across communal lines, with two broad interpretations taking hold (Farrel 1988, Kingsley 1989). For the CNR community, 1968 represented an attempt to find a peaceful resolution that was met with violence and therefore resulted in the emergence of violent, armed conflict. The PUL community, on the other hand, constructed a narrative that posited the events of this time as none other than the latest attempt by Republicans to challenge the constitutional status of Northern Ireland with the civil rights movement as none other than a front for the IRA (Reynolds \& Parr 2020). Such contested perspectives were only consolidated and deepened as a result of the thirty-year conflict of the Troubles and only with the onset of peace in 1998 has it been possible to attempt any sort of recalibration of the memory of Northern Ireland's 1968 (Reynolds 2017, Campbell 2018).

Indeed, in the years following the GFA, and given the change of context that this represented, new possibilities were opened to reconsider pivotal moments of the past. In the case of 1968 specifically, two interrelated developments emerged. The new context of peace facilitated a fresh take where the place of the Northern Irish experience could be located within the increasingly prominent transnational paradigm that had become a staple of 1968 studies (Reynolds 2015). Alongside and connected to this fresh perspective, it also became possible to problematise the dominant, limited, and contested narratives of this period from within. Such opportunities were developed in the 2015 study Sous les pavés ... The Troubles that in turn was used as the underpinning study for a collaboration with NMNI on its representation of this vital period.

Starting with a minor intervention in the permanent galleries of the Ulster Museum in Belfast, this collaboration sought to incorporate the findings of Sous les pavés ... The Troubles via a greater emphasis on the international context of the period (2015). This opened up and facilitated further expansions of the project that would lead to a complete overhaul of the permanent gallery and the development of an educational programme (Reynolds \& Blair 2018). Building on the success thus far, an expanded temporary exhibition entitled Voices of 68 was curated and displayed to 
coincide with fiftieth anniversary of 1968 in 2018. A touring version was also created that travelled to thirty-five destinations across the UK, Ireland, Europe, and the US. Education activities were at the heart of a range of public-facing events and a digital version complemented the physical iterations of the project (Black \& Reynolds 2020). The final stage of this fruitful collaboration saw an adapted version of Voices of 68 installed in the permanent gallery of the Ulster Museum in August 2019. This exhibition, in its various iterations, tells the story of Northern Ireland's 1968 via the juxtaposition of contested narratives on the various stages of the tumultuous weeks and months between October 1968 and January 1969. Combining videoed testimonies with images and documentary footage from the time, it presents a wide range of perspectives from former activists, participants, bystanders, interested observers, and others well placed to comment. Far from favouring a single narrative through an authoritative voice, the exhibition invites visitors to draw their own conclusions on how this crucial period should be remembered and encourages recognition of the complexities of memory in a divided society.

The success and expansion of this collaboration can be attributed to this innovative combination of the methodological approach of oral history and theoretical underpinning of agonism. From the outset, throughout its development, and across the multilayered tapestry of outputs, these two elements were important watchwords (Reynolds \& Parr 2020). The project centred on and showcased oral testimonies that sought to stretch above and beyond the traditional gatekeepers in how this period is remembered. Instead, there was a strong focus on radical multiperspectivity by ensuring that, in addition to the usual suspects, a space was provided for a broad range of views that included those that have hitherto been marginalised in how this story is told. ${ }^{12}$ It was the symbiosis of oral history and agonism that arguably made it possible to reach out to and secure the engagement of thirty participants across a quite diverse spectrum of viewpoints. The oral history approach provided its usual platform for hitherto marginalised voices. Its capacity to do so was enhanced via the deployment of agonism that explicitly welcomed and indeed encouraged perspectives that went beyond the typically dominant narrative. Explaining and being wholly transparent about this innovative approach was an essential factor in ensuring such widespread participation and positive engagement from the interviewees. In addition, by recalibrating the overall perspective on Northern Ireland's 1968 via the international

\footnotetext{
${ }^{12}$ The following people were interviewed as part of the project: Paul Arthur, Paul Bew, Gregory Campbell, Ivan Cooper, Anthony Coughlan, Austin Currie, Anne Devlin, Michael Farrell, Mervyn Gibson, Denis Haughey, Erskine Holmes, Anne Hope, Judith Jennings, Bernadette McAliskey, Nelson McCausland, Eddie McCamley, Eamonn McCann, Chris McGimpsey, Dympna McGlade, Aidan McKinney, Maurice Mills, Geordie Morrow, Mike Nesbitt, Hubert Nichol, Henry Patterson, Brid Rodgers, Bríd Ruddy, Carol Tweedale, Eileen Weir, and Fergus Woods.
} 
context as a starting point, and as a result of the trust invested in NMNI, it was possible to create a sense of 'narrative hospitality' (Ricoeur 1995: 5) that ensured the garnering of a wide range of views that reflected the intercommunal and intracommunal diversity of experiences and memories. The resulting range of outputs and activities enabled the presentation of contested narratives on the past where this agonistic clash of voices was able to provide an innovative and potentially fruitful alternative strategy in the ongoing challenge of dealing with the legacy of the past in Northern Ireland. The fact that the project was able to expand and develop as it did is in itself evidence of the effectiveness of this approach. However, it is when one examines the general reception, examples of feedback, and the tangible impact that its true potential becomes evident.

\section{A blueprint for managing the past in Northern Ireland?}

A vital element of the project's iterative development was a focussed emphasis on garnering feedback from across all those involved and key end-users. Reflections from the general public, project participants, schoolteachers and their pupils, NMNI, and key players in policy development were not only useful in helping ensure the effective development of the various stages of the project, they also provide an insight into the success of the approach and a recognition of its effectiveness. The explicit insistence on multiperspectivity that brought some unexpected voices into the debate on this period was unquestionably uncomfortable for some. Doubts were indeed expressed as to the inclusion of certain viewpoints and, as is evidenced in the feedback examples below, not all those who engaged with the project and its range of outputs were entirely comfortable with the challenge that such inclusion represented:

This is also a very difficult and upsetting topic; Honestly, I was deeply disturbed by the insensitivities of some of the speakers today; I feel that it was very insensitive to include DUP members criticising the events that history agrees were valid and necessary events; Too heavy on the extreme Loyalist/Unionist side. Gregory Campbell? Nelson Mc Causland??; It may trigger people's emotions who lived through the Troubles; Gregory Campbell equating his family being poor with the systematic oppression of Catholics was particularly offensive. ${ }^{13}$

However, such criticisms were generally quite rare with, as exemplified by the reflections of one visitor to the exhibition, an overwhelming acceptance of, and importance attached to, the need to listen to alternative viewpoints, however difficult:

${ }^{13}$ Feedback examples on Voices of 68 exhibition and GCSE study day. 
The exhibition at the Ulster Museum is unsettling - being confronted by some narratives about ' 68 that you believe are wrong. But that is the point and it is quite discomforting. [...] One has to be prepared to listen to other viewpoints. I think that the material should be the start of a critical debate as to what did happen. ${ }^{14}$

The potency of such a polyvocal approach was singled out as vital by one of the exhibition hosts:

The project has demonstrated that as a society, we can engage in difficult events that are within our lived memory. The exhibition was a great tool to do this, mainly because it contained a range of different viewpoints and perspectives. ${ }^{15}$

A project interviewee, and iconic 1968 activist, commented thus on the effectiveness of the approach deployed:

[The] purpose was clearly to approach the past in an innovative manner with the objective of learning from it so as not to repeat history. We cannot change the past. We cannot 'move beyond it'-it shapes us and our present. We can however change how it impacts in the present and shapes the future. ${ }^{16}$

Such a view was shared by a fellow interviewee from the opposite end of the political spectrum:

It is therefore very important that opportunities are provided for differing perspectives to be heard and challenged - the lies that have been created have to be countered where possible. The fact that such opposing views were brought together is an important aspect of this project and whilst it was a great challenge for me, I was made to feel very comfortable in expressing my own views. ${ }^{17}$

An experienced teacher who participated in the project's education programme highlighted the radical impact of this engagement for him:

'Voices of 68' has changed my approach to how I teach the events of 1968/1969 in NI. [...] 'Voices of 68' really is essential viewing for all students on NI in the 1960s. ${ }^{18}$

Such an impact is also discernible amongst the student feedback received, as exemplified from the following testimony of one such pupil:

\footnotetext{
${ }^{14}$ Visitor feedback on Voices of 68 exhibition.

${ }^{15}$ David Robinson, Good Relations Officer at Belfast City Council—written testimony following hosting of exhibition.

${ }^{16}$ Bernadette McAliskey, project participant—written testimony.

${ }^{17}$ Maurice Mills, project participant — written testimony.

${ }^{18}$ Greg Toner, Head of History at Assumption Grammar School, Belfast —written testimony on participation at GCSE study day.
} 
Well, it's kind of really like a really primary source in a way because they were on it and it's like really kind of mind-blowing that they're still here in a way because it seems so long away but it really wasn't and it's just so shocking how that's our history and we get to be a part of that, we get to look back at our history that's so mind-blowing. ${ }^{19}$

In addition to this positive feedback, it is possible to identify and highlight examples of the tangible impact of the project and its approach in terms of the broader question of dealing with the legacy of the past in Northern Ireland. The examples below demonstrate how this has included direct influence amongst important actors and bodies involved in informing and shaping state-led strategies on this most urgent of challenges for the peace process. For example, the following testimony excerpt underscores the potency of the project in helping define NMNI's approach to the past:

From an institutional perspective, this has been a hugely valuable project for NMNI. Its various strands have provided a range of lessons that we can apply to our more general approach to dealing with the challenge of the past in Northern Ireland. The 1968 collaboration in many respects has become a model we can now apply to how we treat other such topics. ${ }^{20}$

The influence of this project on NMNI is equally identifiable when we consider this institution's response to the 2019 public consultation on 'Addressing the Legacy of the past'. Drawing on the example of Voices of 68, it argues:

that a more discerning and critical approach is included in structuring the Oral History Archive, that rather than acting only as a repository, people could record their experiences in a more meaningful way and invest in something that has wider application. This would present much greater opportunities for effective dialogue. ${ }^{21}$

Returning to the education sector, another teacher/participant in the study-day programme set out his perspective on how the project connects to the broader challenges faced:

Projects such as this underscore just how important it is for our young people to make sense of our past and understand how it is that we find ourselves in our current predicament. The 1968 project goes a long way towards helping enhance the level of understanding of what was such pivotally important moment. ${ }^{22}$

\footnotetext{
${ }^{19}$ Student feedback on GCSE study day.

${ }^{20}$ Karen Logan, Senior Curator of History, NMNI — written testimony.

${ }^{21}$ NMNI (2019), 'Addressing the Legacy of Northern Ireland's Past: A Response from National Museums NI' (unpublished document).

${ }^{22}$ Declan White, Head of History at Edmund Rice College, Glengormley, Northern Ireland-written testimony.
} 
Such a perspective was shared by a fellow teacher who outlined his belief that:

the project has made it easier for teachers to confront the difficulties of teaching such a sensitive area of our recent past. [...] Given the importance of education to our future here in Northern Ireland, I believe that this project offers up significant lessons in terms of the ongoing and very difficult debate around how we deal with the legacy of the past as part of the peace process. ${ }^{23}$

The following reflection from a member of the Community Relations Council team provides an insight to the perceived potential of the project within such an influential body:

It is an example of what can be achieved with joint societal responses to such challenges; the presentation of different perspectives through conversations and debates in safe spaces where the focus is on respect for different opinions but a determination to have such discussions. ${ }^{24}$

Finally, consider the following testimony of a FICT commissioner on his direct experience of the impact of this project and its approach:

As author of the unpublished chapter on Education, in the draft FICT report, I can say that the project has helped shape my thinking on the chapter's content. In certain areas it has influenced my conclusions on how teaching Northern Ireland's contested history might be appropriate in a society emerging from conflict. ${ }^{25}$

\section{Conclusion}

There is no suggestion here that the Voices of 68 project is a panacea for the challenge of dealing with the legacy of the past in Northern Ireland. Indeed, the project did meet with some criticisms and difficulties across its development and there are important lessons to be taken into any future initiatives that seek to build on the work to date. Nor is it being suggested that what has been effective in the case of 1968 can be lifted and simply applied to other contentious moments of the region's recent past. The same caution towards any such one-size-fits-all application is an equally important consideration when weighing up the pertinence of such a model in other parts of the world coming to terms with the past as part of a post-conflict pathway to peace.

\footnotetext{
${ }^{23}$ Helen Parks, Education Manager for History, Government and Politics at Council for the Curriculum, Examinations and Assessment (CCEA) - written testimony.

${ }^{24}$ Gemma Attwood, Policy Development Officer at Community Relations Council, Northern Irelandwritten testimony.

${ }^{25}$ Independent commissioner on the Flags, Identity, Culture and Tradition (FICT) commission — written testimony.
} 
However, and with these caveats in mind, the successful development and expansion of the Voices of 68 project, with the symbiotic combination of oral history and agonistic memory at its core, do merit testing in terms of the broader challenge of managing the legacy of the conflict as part of the Northern Ireland peace process. If such an application is able to touch a similar nerve and make further inroads in terms of influencing and informing emergent strategies to address this most urgent and sensitive of issues, then its appropriateness beyond the case of this specific region will certainly be worthy of exploration.

\section{References}

Aras, R., Boyd, D., Marshall, C., Mary, K., Mehmet, M., Mohammad, S., Perez, G., Claudia, P. \& Taminian, L. (2012), Documenting and Interpreting Conflict Through Oral History: A Working Guide (New York, Columbia University).

Armstrong, C.I., Herbert, D. \& Mustad, J.E. (2019), The Legacy of the Good Friday Agreement: Northern Irish Politics, Culture and Art after 1998 (Cham, Springer International). https://doi.org/10.1007/978-3-319-91232-5

Bairner, Alan (2008), 'Still Taking Sides: Sport, Leisure and Identity', in Northern Ireland after the Troubles? A Society in Transition (Oxford, Oxford University Press).

Beiner, Guy (2018), Forgetful Remembrance: Social Forgetting and Vernacular Historiography of a Rebellion in Ulster (Oxford, Oxford University Press). https://doi.org/10.1093/oso/9780198749356.001.0001

Bell, C. (2003), 'Dealing with the Past in Northern Ireland', Fordham International Law Journal, 26(4): 1095-2003.

Bickford, L. (2007), 'Unofficial Truth Projects', Human Rights Quarterly, 29(4): 994-1035. https://doi.org/10.1353/hrq.2007.0036

Black, G. \& Reynolds, C. (2020), 'Engaging Audiences with Difficult Pasts: The Voices of '68 Project at the Ulster Museum, Belfast', Curator. The Museum Journal, 63(1): 21-38. https://doi.org/10.1111/cura.12346

Bouka, Y. (2013), '(Oral) History of Violence: Conflicting Narratives in Post-Genocide Rwanda', Oral History Forum d'histoire orale, 33.

Boyd, S.W. (2019), 'Post-conflict Tourism Development in Northern Ireland: Moving Beyond Murals and Dark Sites Associated with its Past', in R.K. Isaac, E. Çakmak \& R. Butler (eds) Tourism and Hospitality in Conflict-ridden Destinations (Abingdon, Routledge), 226-39. https://doi.org/10.4324/9780429463235-16

Brewer J.D. \& Hayes B.C. (2015), 'Victimhood and Attitudes Towards Dealing with the Legacy of a Violent Past: Northern Ireland as a Case Study', The British Journal of Politics and International Relations, 17(3): 512-30. https://doi.org/10.1111/1467-856X.12050

Brown, K. \& Grant, A. (2016), 'A Lens over Conflicted Memory: Surveying “Troubles” Commemoration in Northern Ireland', Irish Political Studies, 31(1): 139-62. https://doi.org/10.1080/07907184.2015.1126925

Bryson, A. (2016), 'Victims, Violence and Voice: Transitional Justice, Oral History and Dealing with the Past', Hastings International and Comparative Law Review, 39(2).

Byrne, J. (2014), 'Flags and Protests: Exploring the Views, Perceptions and Experiences of People Directly and Indirectly Affected by the Flag Protests'. http://uir.ulster.ac.uk/28386/1/Report.pdf [accessed 28 June 2018]. 
Campbell Sarah (2018), “We Shall Overcome”? The Good Friday/Belfast Agreement and the Memory of the Civil Rights Movement', Open Library of Humanities, 24(1): 1-25. https://doi.org/10.16995/olh.259

Cento Bull, Anna \& Hansen, Hans Lauge (2016), 'On Agonistic Memory’, Memory Studies, 9(4): 390-404. https://doi.org/10.1177/1750698015615935

Cento Bull, A. \& Hansen, H.L. (2020), 'Agonistic Memory and the UNREST Project', Modern Languages Open, (1): 20. https://doi.org/10.3828/mlo.v0i0.319

Cochrane, F. (2013), Northern Ireland: The Reluctant Peace (New Haven, CT, Yale University Press). https://doi.org/10.12987/yale/9780300178708.001.0001

Cochrane, F. (2020), Breaking Peace: Brexit and Northern Ireland (Manchester, Manchester University Press). https://doi.org/10.7765/9781526142566

CPG (Consultative Group of the Past) (2009), Report of the Consultative Group of the Past. https://cain.ulster.ac.uk/victims/docs/consultative_group/cgp_230109_report.pdf

Crooke, E. (2007), Museums and Community: Ideas, Issues, and Challenges (Abingdon, Routledge).

Dawson, G. (2014), 'The Desire for Justice, Psychic Reparation and the Politics of Memory in "Postconflict" Northern Ireland', Rethinking History, 18(2): 265-88. https://doi.org/10.1080/13642529.2013.858450

Dawson, G. (2017), "The Meaning of "Moving On": From Trauma to the History and Memory of Emotions in 'Post-conflict Northern Ireland', Irish University Review, 47(1) 82-102. https://doi.org/10.3366/iur.2017.0258

Della Porta, D. (2014), Methodological Practices in Social Movement Research (Oxford, Oxford University Press). https://doi.org/10.1093/acprof:oso/9780198719571.001.0001

Dingley, J. (2005), 'Constructive Ambiguity and the Peace Process in Northern Ireland', Low Intensity Conflict \& Law Enforcement, 13(1): 1-23. https://doi.org/10.1080/09662840500223531

Dybris McQuaid, S. (2016), 'Passive Archives or Storages for Action? Storytelling Projects in Northern Ireland', Irish Political Studies, 31(1): 63-85. https://doi.org/10.1080/07907184.2015.1126929

Farrell, Michael (ed.) (1988), Twenty Years on (Dingle, Mount Eagle Publications).

Fenton, S. (2019), 'How the Irish Language became a Pawn in a Culture War', New Statesman, 5 July 2019. https://www.newstatesman.com/politics/northern-ireland/2019/07/how-irish-languagebecame-pawn-culture-war

Field, S. (2011), 'Disappointed Remains: Trauma, Testimony and Reconciliation in Post-Apartheid South Africa', in D. Ritchie (ed.) The Oxford Handbook of Oral History (Oxford, New York, Oxford University Press), 142-58. https://doi.org/10.1093/oxfordhb/9780195339550.013.0010

Foster, R. (1988), Modern Ireland, 1600-1972 (London, Penguin).

Frisch, M. (1990), Shared Authority: Essays on the Craft and Meaning of Oral and Public History (Albany, NY, State University of New York Press).

Halbwachs, M. (1925), Les Cadres Sociaux de la Mémoire (Paris, Alcan).

Halbwachs, M. (1950), La Mémoire Collective (Paris, Presses Universitaires de France).

Halliday, D. \& Ferguson, N. (2016), 'When Peace is Not Enough: The Flag Protests, the Politics of Identity \& Belonging in East Belfast', Irish Political Studies, 31(4): 525-40. https://doi.org/10.1080/07907184.2015.1084291

Hamber, B. (2009), Transforming Societies After Political Violence: Truth, Reconciliation and Mental Health (New York, Springer). https://doi.org/10.1007/978-0-387-89427-0

Hamber, Brandon \& Kelly, Gráinne (2016), 'Practice, Power and Inertia: Personal Narrative, Archives and Dealing with the Past in Northern Ireland', Journal of Human Rights Practice, 8(1): 25-44. https://doi.org/10.1093/jhuman/huw001

Hennessey, T. (1997), A History of Northern Ireland: 1920-1996 (Basingstoke, Macmillan). https://doi.org/10.1007/978-1-349-26066-9 
Humphrey, M. (2002), The Politics of Atrocity and Reconciliation: From Terror to Trauma (London, New York, Routledge).

Jessee, E. (2011), 'The Limits of Oral History: Ethics and Methodology Amid Highly Politicized Research Settings', The Oral History Review, 38(2): 287-307. https://doi.org/10.1093/ohr/ohr098

Kaifala, J.B. (2014), 'Transitional Justice in Sierra Leone: Oral History, Human Rights, and Post-conflict Reconciliation', Forum, 34.

Kingsley, Paul (1989), Londonderry Revisited: A Loyalist Analysis of the Civil Rights Controversy (Belfast, Belfast Publications).

Lawther, C. (2014), Truth, Denial and Transition: Northern Ireland and the Contested Past (Abingdon, Routledge).

Lee, J.J. (1989), Ireland 1912-1985 (Cambridge, Cambridge University Press).

Lundy, P. \& McGovern, M. (2001), 'The Politics of Memory in Post-conflict Northern Ireland', Peace Review, A Journal of Social Justice, 1(1): 27-33. https://doi.org/10.1080/10402650120038116

Lynd, S. (1993), 'Oral History From Below', The Oral History Review, 21(1): 1-8. https://doi.org/10.1093/ohr/21.1.1

McDowell, S. \& Braniff, M. (2014), Commemoration as Conflict: Space, Memory and Identity in Peace Processes (Basingstoke, Palgrave Macmillan).

McEvoy, K. \& Bryson, A. (2016), 'Justice, Truth and Oral History: Legislating the Past "from Below" in Northern Ireland', Northern Ireland Legal Quarterly, 67(1): 67-90.

McEvoy, K. \& McConnachie, K. (2012), 'Victimology in Transitional Justice: Victimhood, Innocence and Hierarchy', European Journal of Criminology, 9(5): 527-38. https://doi.org/10.1177/1477370812454204

McGrattan, Cillian \& Hopkins, Stephen (2017), 'Memory and Post-conflict Societies: From Contestation to Integration?', Ethnopolitics, 16(5): 488-99. https://doi.org/10.1080/17449057.2016.1218644

McKittrick, D. \& McVea, D. (2001), Making Sense of the Troubles (London, Penguin).

Mouffe, Chantal (2000), The Democratic Paradox (London, Verso).

Mouffe, Chantal (2005), On the Political (London, Routledge).

Mouffe, Chantal (2012), 'An Agonistic Approach to the Future of Europe', New Literary History, 43: 629-40. https://doi.org/10.1353/nlh.2012.0038

NIO (Northern Ireland Office) (2014), 'The Stormont House Agreement'. https://www.gov.uk/government/publications/the-stormont-house-agreement

NIO (Northern Ireland Office) (2018), 'Addressing the Legacy of Northern Ireland's Past', May 2018. https://www.gov.uk/government/consultations/addressing-the-legacy-of-northern-irelands-past

NIO (Northern Ireland Office) (2019), 'Addressing the Legacy of Northern Ireland's Past. Analysis of the consultation responses', July 2019. https://assets.publishing.service.gov.uk/government/ uploads/system/uploads/attachment_data/file/814805/Addressing_the_Legacy_of_the_Past_-_ Analysis_of_the_consultation_responses.pdf

O'Toole, M. (2021), 'Brexit Isn't the Cause of the Belfast Riots-But It Is Harming Political Reconciliation', The Guardian, 14 April 2021. https://www.theguardian.com/commentisfree/2021/ apr/14/belfast-riots-brexit-good-friday-peace-deal

Park, R. (2013), 'Remembering Resistance, Forgetting Torture: Compromiso and Gender in Former Political Prisoners' Oral History Narratives in Post-dictatorial Argentina', History of Communism in Europe, 4: 87-111. https://doi.org/10.5840/hce201345

Patterson, H. (2007), Ireland Since 1939: The Persistence of Conflict (Dublin, Penguin).

Pinkerton P. (2012), 'Resisting Memory: The Politics of Memorialisation in Post-conflict Northern Ireland', The British Journal of Politics and International Relations, 14(1): 131-52. https://doi.org/10.1111/j.1467-856X.2011.00458.x

Portelli, A. (1991), The Death of Luigi Trastulli, and Other Stories: Form and Meaning in Oral History (Albany, NY, State University of New York Press). 
Potter, M. (2016), Dealing with the Past in Northern Ireland. https://www.assemblyresearchmatters.org/2016/09/22/dealing-with-the-past-in-northern-ireland/

Power, M. (2011), Building Peace in Northern Ireland (Liverpool, Liverpool University Press).

Prince, S. (2007), Northern Ireland's 68. Civil Rights, Global Revolt and the Origins of the Troubles (Dublin, Irish Academic Press).

Purdie, B. (1990), Politics in the Streets: Origins of the Civil Rights Movement in Northern Ireland (Belfast, Blackstaff Press).

Reynolds, C. (2015), Sous les pavés ... The Troubles: Northern Ireland, France and the European Collective Memory of 1968 (Bern, Peter Lang). https://doi.org/10.3726/978-3-653-02119-6

Reynolds, C. (2017), 'Northern Ireland's 1968 in a Post-Troubles Context', Interventions, 19(5): 631-45. https://doi.org/10.1080/1369801X.2017.1336462

Reynolds, C. \& Blair, W. (2018), 'Museums and "Difficult Pasts": Northern Ireland's 1968', Museum International, 70(3-4): 12-25. https://doi.org/10.1111/muse.12206

Reynolds, C. \& Parr, C. (2020), 'Northern Ireland's 1968 at 50: Agonism and Protestant Perspectives on Civil Rights' Twentieth Century British History. https://doi.org/10.1080/13619462.2020.1785291

Ricoeur, P. (1995), 'Reflections on a New Ethos for Europe', Philosophy and Social Criticism, 21(5/6): 3-13. https://doi.org/10.1177/0191453795021005-602

Ritchie, D.A. (2014), Doing Oral History (Oxford, Oxford University Press).

Savage, R. (2019), “New Culture War”: Northern Ireland's LGBT+ Community Fights for Gay marriage', Thomson Reuters Foundation News. http://news.trust.org/item/20190327074742yyrq6/ [accessed 19 September 2019].

Schaffer, K. \& Smith, S. (2004), 'Conjunctions: Life Narratives in the Field of Human Rights', Biography, 27(1): 1-24. https://doi.org/10.1353/bio.2004.0039

Smyth, Jim (2017), Remembering the Troubles: Contesting the Recent Past in Northern Ireland (Notre Dame, IN, University of Notre Dame Press). https://doi.org/10.2307/j.ctvpj7cpp

Strangleman, T. (2017), 'Portrait of a Deindustrializing Island', in G. Crow \& J. Ellis (eds) Revisiting Divisions of Labour: The Impact and Legacies on a Modern Classic (Manchester, Manchester University Press), 55-68. https://doi.org/10.7765/9781526116239.00009

Thompson, P. (1998), 'The Voice of the Past: Oral History', in R. Perks \& A. Thomson (eds) The Oral History Reader (Abingdon, Routledge), 25-31.

Thomson, A. (2007), 'Four Paradigm Transformations in Oral History', The Oral History Review, 34(1): 49-70. https://doi.org/10.1525/ohr.2007.34.1.49

Tonge, J. (2013), Northern Ireland: Conflict and Change (Abingdon, Routledge). https://doi.org/10.4324/9781315837871

Tonge, J. (2016), 'The Impact of Withdrawal from the European Union upon Northern Ireland', The Political Quarterly, 87(3): 338-42. https://doi.org/10.1111/1467-923X.12288

Viggiani, E. (2014), Talking Stones: The Politics of Memorialization in Post-conflict in Northern Ireland (New York, Berghahn Books).

Wali, F. (2018), 'An Oral History Approach to Post-conflict Identity in Bosnia and Herzegovina', Oral History, 46(1): 67-77.

Walker, P. \& Carroll, R. (2019), 'MPs Vote to Extend Abortion and Same-sex Marriage Rights to Northern Ireland', The Guardian, 9 July 2019. https://www.theguardian.com/uk-news/2019/jul/09/ mpsvote-to-extend-same-sex-marriage-tonorthern-ireland 
To cite the article: Chris Reynolds (2021), 'The symbiosis of oral history and agonistic memory: Voices of 68 and the legacy of the past in Northern Ireland', Journal of the British Academy, 9(s3): 73-94.

DOI https://doi.org/10.5871/jba/009s3.073

Journal of the British Academy (ISSN 2052-7217) is published by

The British Academy, 10-11 Carlton House Terrace, London, SW1Y 5AH www.thebritishacademy.ac.uk 